Лучицька М. $\mathrm{C}$. кандидат філологічних наук, старший викладач

кафедри практики германських мов Кіровоградського держсавного педагогічного університету імені Володимира Винниченка

\title{
НАРАТИВНА ПАЛІТРА ОПОВІДАННЯ У. С. МОЕМА «СИЛА ОБСТАВИН»
}

У статті аналізується оповідання У. С. Моема «Сила обставин» з позиції наратології. Виокремлюються суб'єкти нараџії, наративні моделі, що домінують. Досліджуються наративні особливості прозового твору як способи передачі емочій, настроїв, життєвої позичії автора, загальнолюдських иінностей. Простежується типова для творів такого жанру структура ведення розповіді.

Клюові слова: наратологія, наративні моделі, прозовий твір.

В статье исследуется рассказ В. С. Моэма «Сила обстоятельств» $c$ точки зрения нарратологии. Выделяются субъекты наррачии, доминирующие нарративные модели. Исследуются нарративные особенности прозаического произведения как способы передачи эмочий, настроения, жизненной позиции автора, общечеловеческих цеенностей. Прослеживается типичная для произведений этого жанра структура ведения повествования.

Ключевые слова: нарратология, нарративные модели, прозаическое произведение.

The short story "The Force of Circumstance" by W. S. Maugham is being analyzed from the point of view of narratology in the given article. The subjects of narration and the dominating narrative patterns are distinguished in it. The narrative peculiarities of a piece of prose as the means of conveying the emotions, shades of the mood, life credo of the author, and common human values are investigated. The structure of narration typical of the literary works of such a genre is being traced here.

Keywords: narratology, narrative patterns.

Проза XX століття, зокрема новели та оповідання представників світової літератури, вирізняється експресією, тонким психологізмом, великою кількістю засобів вираження емоційних станів, настроїв, віянь епохи та індивідуально конкретних засад світогляду людини. Точність та художність експлікації певних явищ значною мірою залежать від обраної письменником форми повістуван- 
ня та способів іiі втілення у загальній картині дієгезису твору. Саме тому не остання роль в осягненні, в адекватній перцепції високохудожніх психологічних прозових творів належить нарації, iї формам, суб'єктам, прийомам.

Наративний аналіз прозових творів (як великих, так і малих за обсягом) у межах літературознавства XX - XXI століть набуває широкого використання в дослідженнях світових та українських наратологів i літературознавців, таких як Ж. Женетт [Женетт 1998], Дж. Прінс [Prince 2003], М. Ткачук [Ткачук 2007], Л. Мацевко-Бекерська [Мацевко-Бекерська 2008] та багатьох інших.

Наше дослідження - спроба окреслити наративні особливості невеликого прозового твору відомого англомовного письменника XX століття як способи передачі емоцій, настроїв, життєвих кредо автора, загальнолюдських цінностей, що матеріалізуються в завершеній наративній палітрі оповідання. Матеріалом для дослідження слугує оповідання «Сила обставин» (“The Force of Circumstance") [Modern English Short Stories 1978] У. С. Моема.

Аналізуючи обране оповідання У.С. Моема, необхідно зазначити, що як прозаїк письменник отримав визнання за притаманну йому майстерність оповідача, відточеність літературної форми, яка в його творчості заснована на принципі простоти, дохідливості та милозвучності [ЕС 2006 : 197-198]. Нарація творів письменника одночасно 3 яскраво вираженим соціально-критичним спрямуванням гармонійно поєднує традиції виваженої англійської прози та новаторство автора.

Аналізоване оповідання демонструє домінування третьоособової нарації. У наративі функціонує яскраво виражений гетеродієгетичний, екстрадієгетичний наратор, що займає позицію позазнаходження щодо дієгезису та виявляє всевідну точку зору на подієві колізії твору.

Позиція позазнаходження об'єктивує розповідь, зводячи іiі до емоційно нейтрального викладу подій, який у тексті аналізова- 
ного твору оживлюється психологічно забарвленими вкрапленнями описів та діалогів.

Опис в оповіданні «Сила обставин» не обмежується змалюванням зовнішніх обставин, фону, на якому розгортаються події. Описові епізоди матеріалізуються в тексті також здебільшого в формі третьоособового наратування із залученням ефекту ока камери та стилістично насичених епітетів. Зокрема, третьоособова нарація, що інтродукує реципієнтові мікросвіт героїв оповідання, не обмежується сухим поданням екстер'єру та інтер'єру, не зводиться до банального переліку певних рис характеру, до чіткого «змалювання» зовнішності чи стандартних характеристик персонажу. Інтродукція мікросвіту героїв оживлена епітетами, експресивними діалогами, іронічними рефлексіями, прихованими в авторському наратуванні.

Кожне речення, що «вимальовує» дієгетичні колізії твору, сповнене романтизованого психологізму, тонкого розуміння душі. Так, героїня оповідання Доріс постає в ореолі екзотичної природи Малайї, яка (як істинна англійка), з одного боку, контрастує з екзотичним мікросвітом нового для неї краю, а 3 іншого - прагне гармонійного співіснування 3 цим новим мікросвітом, оскільки він асоціюється 3 новим, щасливим життям і найдорожчою у цьому житті людиною.

Перші рядки твору не мають на меті інтригувати: особа жіночої статі (у першому та другому абзацах тексту вона ідентифікується лише як “she” [MESS 1978 : 250]) чекає на свого чоловіка, щоб разом з ним поснідати. Однак перебіг подальших подій почасти набуває загадкової символічності, демонструє деяку недомовленість, загадку, таїну (поява загадкової незнайомки $з$ дитиною, розмови чоловіка $з$ незнайомцями, зміни настрою, виразу обличчя та ін.). Втаємничення реципієнта в дещо інший (незвичний) світ героя відбувається в межах раніше згадуваної третьоособової нарації екстрадієгетичного, гетеродієгетичного автора-наратора. 
Повільний плин часу в момент очікування підсилюється описами природи: річка, яку помічає жінка крізь частково підняті жалюзі, має мертво-блідий колір під бездиханним полуденним сонцем. Підкреслюючи екзотичність клімату країни, автор вживає прикметники "ashy and wan" [MESS 1978 : 250], тим самим виокремлюючи кольори типового, рутинного дня в умовах спеки, що «спопеляє». Опис природи підкреслює монотонність та одноманітність існування в години такої нестерпної спеки. Як контраст спів пташки, що навіює ностальгічні спогади про Англію. Контрастність співу пташки підсилюється несподіваним використанням прикметників “mellifluous and rich” [MESS 1978 : 250], що надають живих, яскравих барв сірій, спопелілій від спеки реальності.

Ім'я Доріс уперше згадується лише в діалозі з чоловіком. Розкриття характерів героїв відбувається крізь звичну третьоособову нарацію автора-наратора зі значною кількістю психологічно забарвлених епітетів. Однак наратування це для реципієнта асоціюється передусім з прихованими в розповіді рефлексіями самих героїв. Так, зокрема, Гай (чоловік Доріс) візуалізується крізь психологічно тонке спостереження: "He was twenty-nine, but he was still a schoolboy; he would never grow up" [MESS 1978 : 251]. Доказом того, що це нараторське спостереження подається крізь призму бачення чоловіка очима самої Доріс є пояснення автора-наратора: саме тому (через цю дитинність, відкритість, відданість) вона і вирішила пов'язати з ним життя (не зважаючи на самотню, хвору матір, на розмірене життя, що залишились у світі «старому», звичному, пов’язаному з ії рідною країною).

Крім третьоособової нарації гетеродієгетичного екстрадієгетичного наратора, що суттєво домінує в барвистій наративній палітрі оповідання, характеротворчу функцію виконують діалоги, які в прозі У.С. Моема досить часто перейняті гумором, іронією, а інколи - самоіронією героя. Репліка Доріс, адресована Гаєві ("You're an ugly little fat man, Guy, but you've got charm. I can't help loving you” [MESS 1978 : 251]), налаштовує на невимушену, довір- 
ливу атмосферу відкритих, не обмежених умовностями людей, які у межах своєї родини змогли створити свій власний мікрокосм.

Атмосфера довіри та невимушеності, освітлена гумором i тонкою іронією, що матеріалізуються в тексті твору безпосередньо крізь голоси героїв, однак, має «темні плями», які в подальшому перебігові подій увиразнюються крізь нараторські штрихиспостереження. Пункт відліку «згущення фарб» - поява загадкової жіночої постаті з дитиною на руках, яка змушує Гая відчувати дискомфорт.

Душевний дискомфорт героя відбивається у психологічних «замальовках» змін настрою в різних ситуаціях, пов'язаних із появою незнайомки: "His face, usually so cheerful, had borne a sullen look"; "He frowned a little" [MESS 1978 : 253]; "His eyes rested for a moment on a native woman, but he did not speak"; "It (his face М. Л.) was deathly white ..." [MESS 1978 : 258] і т. п.

Навіть рутинна гра в теніс 3 появою малайської жінки змінює свій звичний плин. Спостереження наратора відображається в ретроспективній розповіді, що підсилює контраст між звичайним та спричиненим появою незнайомки станом героя-гравця: “Не played very badly. Generally he gave her fifteen and beat her, but today she won easily. And he played silently. Generally he was a noisy player, shouting all the time, cursing his foolishness when he missed a ball and chaffing her when he placed one out of her reach" [MESS 1978 :259]. Увиразнення душевного дискомфорту акумулюється в роздумі Дopic - "She had never seen him with that set face" [MESS 1978 : 259]; "Doris thought she heard a little sigh. It vaguely disturbed her. Guy was always so full of gaiety" [MESS 1978 : 260]. Рефлексії героїні ніби навмисне подаються в контексті нараторської розповіді. Тепер і сама Доріс - «екстрадієгетичний» спостерігач, який прагне відкрити причину різких змін у поведінці Гая.

Втаємничення реципієнта у життєву драму героїв відбувається крізь поступове нагромадження описових деталей, які підсилюють візуалізацію душевного дискомфорту та психічної напруги 
людини, що приховує щось важливе: прикметники “nervous and irritable", "restless", “silent and abstracted” [MESS 1978 : 263] акселерують антиципацію моменту необхідного катарсису заради подолання душевних тортур. Крім стилістично забарвлених епітетів, автор-наратор знову вдається до паралелі між світом природи та настроєм, переживаннями людини. Річка, згадувана на початку оповідання як компонент розміреного, одноманітного, «спопелілого» від спеки життя, зараз ніби дублює фатальність та неминучість краху цієї розміреної одноманітності: “At their feet, with a mighty, formidable sluggishness, silent, mysterious and fatal, flowed the river. It had the terrible deliberation and the relentlessness of destiny" [MESS 1978 : 263].

Момент зізнання Гая в особистій таємниці, яка руйнувала звичний плин життя, автор-наратор зводить до спонтанної промови у формі першої особи однини, що інтродукується фразою, де сконцентроване прагнення не залишати недомовок в їхніх стосунках: "Doris, I've got something to say to you," - he said suddenly" [MESS 1978 : 263] (курсив наш. - М. Л.). Серйозні побоювання наслідків викриття цієї історії маскують дещо сухі зауваження героя: “'It's rather a long story. I'm afraid it's not a very nice one and I find it rather difficult to tell. I'm going to ask you not to interrupt me, or to say anything, till I've finished' [MESS 1978 :263]. Першоособове наратування зміщує вектор уваги із зовнішніх змін настрою на ретроспективну реконструкцію подій та внутрішніх переживань, які передували появі малайської незнайомки в родині Доріс. Першоособова нарація героя - сповідь, яка навіки перекреслює образ «дитинно чистого школяра» в очах його дружини.

Історія-сповідь стає точкою відліку руйнування родини. Те, що для «білих» жителів Малайї було майже нормою життя, для Доріс виявляється річчю неприпустимою: іï чоловік довгих десять років (хоч і до їхнього шлюбу) мав стосунки з місцевою жителькою, яка народила йому трьох дітей (цей факт автор подає в невеликому психологічно напруженому діалозі, що на деякий час пе- 
рериває монотонну я-нарацію Гая й акцентує важливість поняття родина і діти для героїні). Слабке виправдання чоловіка (“I wasn't in love with her, not even at the beginning. I only took her so as to have somebody about the bungalow. I think I should have gone mad if I hadn't, or else taken to drink. I was at the end of my tether. I was too young to be quite alone. I was never in love with any one but you" [MESS 1978 : 266]) не допомагає порозумітись, а лише погіршує ситуацію. Цей факт увиразнюється у зізнаннях, що ніби самовиправдовують героя місцевими традиціями Малайї: “I couldn't expect you to understand. The circumstances out here are peculiar (курсив наш М. Л.). It's the regular thing. Five men out of six do it. I thought perhaps it would shock you and I didn't want to lose you" [MESS 1978 : 267].

Передчуття трагічного фіналу цієї розмови для родини наратор криє в штрихах-спостереженнях щодо змін настрою після переосмислення зізнань Гая: "She sat motionless"; "She was pale next day and he could see that she had not slept"; " ... she talked as usual, but without ease; she spoke of this and that as though she were making conversation with a stranger" [MESS 1978 : 269]; "Her face grew a trifle paler"; "She looked at him suddenly and her eyes were cold and hostile" [MESS 1978 : 271]. Опис змін настрою в наративі йдуть поруч зі змінами в звичному плині життя молодої родини: “Не heard her lock the door of her bedroom"; "She turned her face away and he kissed her cheek" [MESS 1978 : 269]; "I've had the bedroom in my room taken away. It took up so much space" [MESS 1978 : 271] та ін. Разом такі деталі-спостереження довершують картину незворотного руйнування виваженого, щасливого родинного життя.

Момент розриву, остаточного руйнування сім’ї у наративі оповідання обіграється із залученням наскрізних деталей: пароплав, що кожного місяця зупинявся в гирлі річки, привозячи пошту, стає засобом повернення Доріс до Англії; різкі, несподівані звуки, що на початку твору візуалізуються як несподівано живий, приємний спів пташки, який нагадує жінці рідні краї, тут, у фінальній частині повістування, модифікуються в різкий, пронизливий вереск місцевої 
ящірки й т. п. Незвичне наративне рішення - діалог Гая зі своїм старшим сином як фінал оповідання знаменує незворотній процес повернення до попереднього життя. Трансформація ця підкреслюється автором і тим, що одяг, у якому чоловік тепер виходить до вечері, візуалізує довершений образ місцевого мешканця Малайї.

Дитинність, відкритість героя, що надавала сірому одноманіттю живих, яскравих барв на початку твору, зараз - причина побоювань за ймовірність його чесності в новому спільному з Доpic житті. "The circumstances out here are peculiar ..." [MESS 1978 : 267] - слабке виправдання власних вчинків людини, що має свої переконання та стійкі уявлення щодо моралі, родини, доброї слави. На противагу Гаю, Доріс - безперечно сильна, цілісна особистість. Ця непорушна цілісність їі особи, непорушність переконань - причина безперспективності стосунків з людиною, яка легко піддається «силі обставин». Між рядками твору автор-наратор натякає: сила духу героїв занадто різна, щоб вони мали спільне майбутнє.

Отже, оповідання У. С. Моема «Сила обставин» - самобутній зразок традиційної прози ХХ століття, який крізь живі епітети, психологічні портрети, наскрізні деталі, діалоги, описи розкриває автора як тонкого психолога, котрий виявляє симпатію до особистості цілісної, зі сформованим світоуявленням, світосприйманням, в якому немає місця подвійному життю, нерішучості, зрадливій мінливості душі. Наскрізне використання третьособової нарації зі всевідним екстрадієгетичним, гетеродієгетичним наратором підносить образ змальованої у творі молодої родини до образу-символу неможливості співіснування занадто різних за своєю ціннісною природою індивідів. Розмаїта наративна палітра оповідання із наскрізним домінуванням повістування від третьої особи, що поєднує, а інколи - i змішує сірі, попелясті кольори звичного плину життя з вербалізованими вибухами емоцій замилування, подиву, обурення й зрештою суцільного розчарування, чітко окреслює життєве кредо митця: сила обставин - занадто слабкий аргумент у виправдовуванні людської слабкодухості, недосконалості, моральної незрілості. 


\section{БІБЛІОГРАФІЯ}

Женетт 1998 - Женетт Жерар. Фигуры. В 2-х томах / Жерар Женетт. - . - Том 2. М.: изд-во им. Сабашниковых, 1998. - 472 с.

ЕС 2006 - Зарубіжні письменники. Енциклопедичний словник. У 2 т. - Т. 2: Л-Я / Заред. Н. Михальської та Б. Щавурського. - Тернопіль: Навчальна книга. Богдан, 2006. -864 c.

Мацевко-Бекерська 2008 - Мацевко-Бекерська Л. Українська мала проза кінця XIX - початку XX століть у дзеркалі наратології: [монографія] / Лідія Василівна Мацевко-Бекерська. - Львів: Сплайн, 2008. - 408 с.

Ткачук 2007 - Ткачук М. П. Наративні моделі українського письменства / М. П. Ткачук. - Тернопіль: ТНПУ, Медобори, 2007. - 464 с.

Ткачук 2002 - Ткачук О. М. Наратологічний словник. / О. М. Ткачук. - Тернопіль: Астон, 2002. - 173 с.

MESS 1978 - Making It All Right. Modern English Short Stories. - Moscow: Progress Publishers, 1978. $-457 \mathrm{p}$.

Prince 2003 - Prince G. A Dictionary of Narratology. Revised Edition / G. Prince. Lincoln and London: University of Nebraska Press, 2003. - $126 \mathrm{p}$.

Стаття надійшла 2 вересня 2013 p. 